\title{
Intracranial-extracranial meningioma mimicking an aggressive skull bone tumor
}

\author{
Amit Agrawal $^{1}$, K.V. Murali Mohan ${ }^{2}$, Vissa Shanthi ${ }^{3}$, \\ Umamaheshwar Reddy ${ }^{4}$
}

Narayana Medical College Hospital, Chinthareddypalem, Nellore, Andhra Pradesh, India

${ }^{1}$ Professor of Neurosurgery, Department of Neurosurgery

${ }^{2}$ Professor of Pathology, Department of Pathology

${ }^{3}$ Associate Professor of Pathology, Department of Pathology

${ }^{4}$ Assistant Professor of Radiology, Department of Radiology

\begin{abstract}
Intracranial meningiomas with extracranial extension are rare lesions with only few reported cases in literature. In present article we report a case of 62 year male patient presented with progressive swelling over right side frontal region of 2 year duration. In our case the tumor was in close proximity to right fronto-parietal suture and there was a possibility that suture line could have paved the way for its extracranial spread and also there was evidence of transdiploic extension on histopatholgical examination.
\end{abstract}

Key words: Meningioma, head injury, extracranial meningioma, intracranialextracranial.

\section{Introduction}

Meningioma account for $24-30 \%$ of primary intracranial tumors and typically arises in proximity to the meninges $(1,2,3)$. Intracranial meningiomas with extracranial extension are rare lesions with only few reported cases in literature (3-8). In present article we report a case of intracranial and extra-cranial menigioma.

\section{Case report}

A 62 year male patient presented with progressive swelling over right side frontal region of 2 year duration. Weakness of left upper and lower limbs of one month duration. There was history of headache and vomiting for last 3-4 days. Local examination revealed a non-tender, hard swelling over right fronto-parietal region, non-pulsatile, with bruit. Skin over the swelling was healthy and there were no prominent vessels. There was history of trauma at the same site about 15 year back. His general and systemic examination was unremarkable. There was mild upper motor neuron type of weakness of left facial nerve. Other cranial nerves including fundus were normal. He was conscious, alert and oriented to time, place and person. There was grade 4/5 weakness of left upper and lower limbs. Deep tendon reflexes were exaggerated on left side and were normal on right side. Planter was extensor on left side and was flexor on right side. CT scan brain plain with bone window revealed a large tumor consisting of intracranial and extracranial parts with erosion of the calvaria involving right frontal and parietal and crossing the coronal suture on right 
side (Figure 1 A-F). The tumor was invading the parenchyma and there was significant peri-lesional edema. Based on the imaging findings a high grade malignant lesion was considered. The patient underwent right fronto-parietal craniotomy and total excision of the tumor including excision of the involved bone. The tumor was attached to the dural and infiltrating the bone. It could be easily separated from the underlying brain parenchyma. Histopathological examination of the tumor confirmed the diagnosis of meningioma (Figure 2 and 3). The patient recovered well and the postoperative course was uneventful.

\section{Discussion}

The reported incidence of intracranial meningiomas with extracranial extension is up to $20 \%$ of cases $(9,10)$.
There is strong evidence there is an elevated risk brain tumor after head trauma particularly for meningiomas in males (1, 11-16). Many explanations have been put forward to explain extracranial spread of tumor and the extracranial extension in meningiomas may occur by direct extension of an intracranial meningioma through a natural, traumatic, or iatrogenic skull defect $(17,18)$. This may occur through skull foramina, through the supraorbital fissure (into the orbit), through the cribriform plate (into the nasal cavities and nasopharynx), through floor of middle cranial fossa (into paranasal sinuses and pterygoid region) and extracranial extension through the suture line of the skull $(4,9$, 10, 19-23). In a case report the transdiploic extension was suggested as the underlying mechanism for the extracranial spread of the meningioma (8).

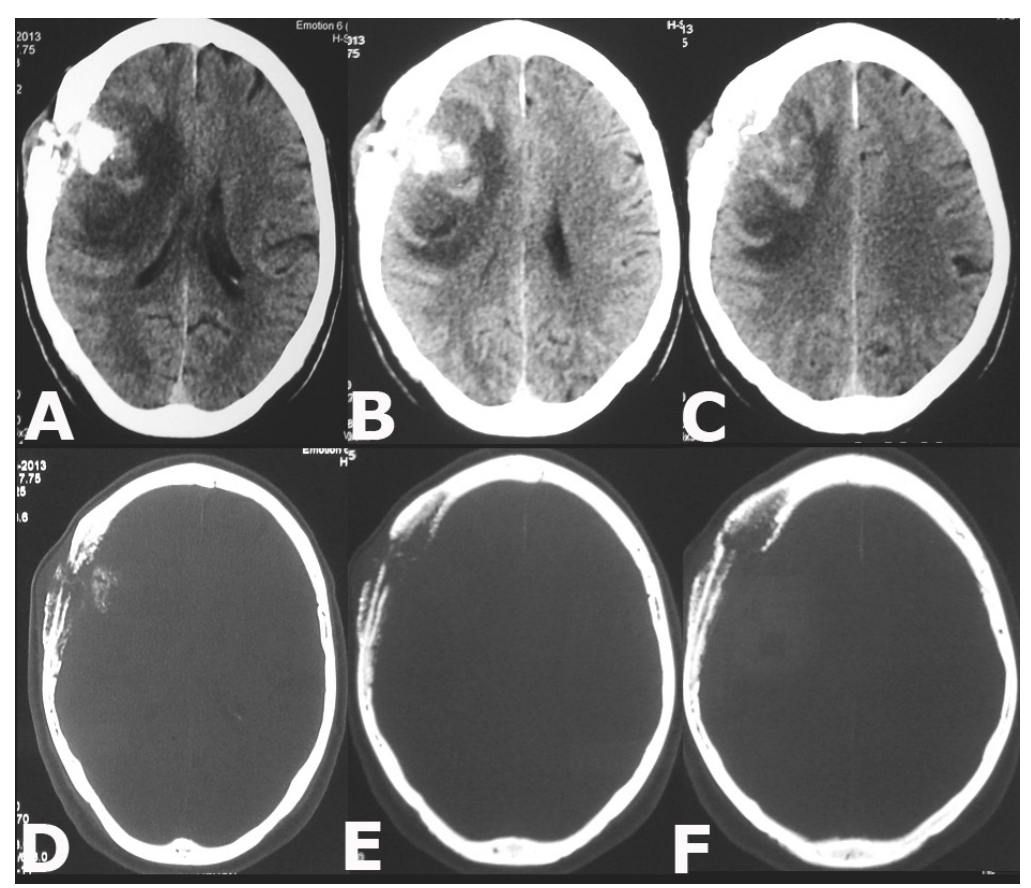

Figure 1

(A-F) CT scan brain showing extensive osteolytic lesion in right fronto-parietal region with intra-extracranial components and adjacent hyperostosis of frontal and parietal bones 


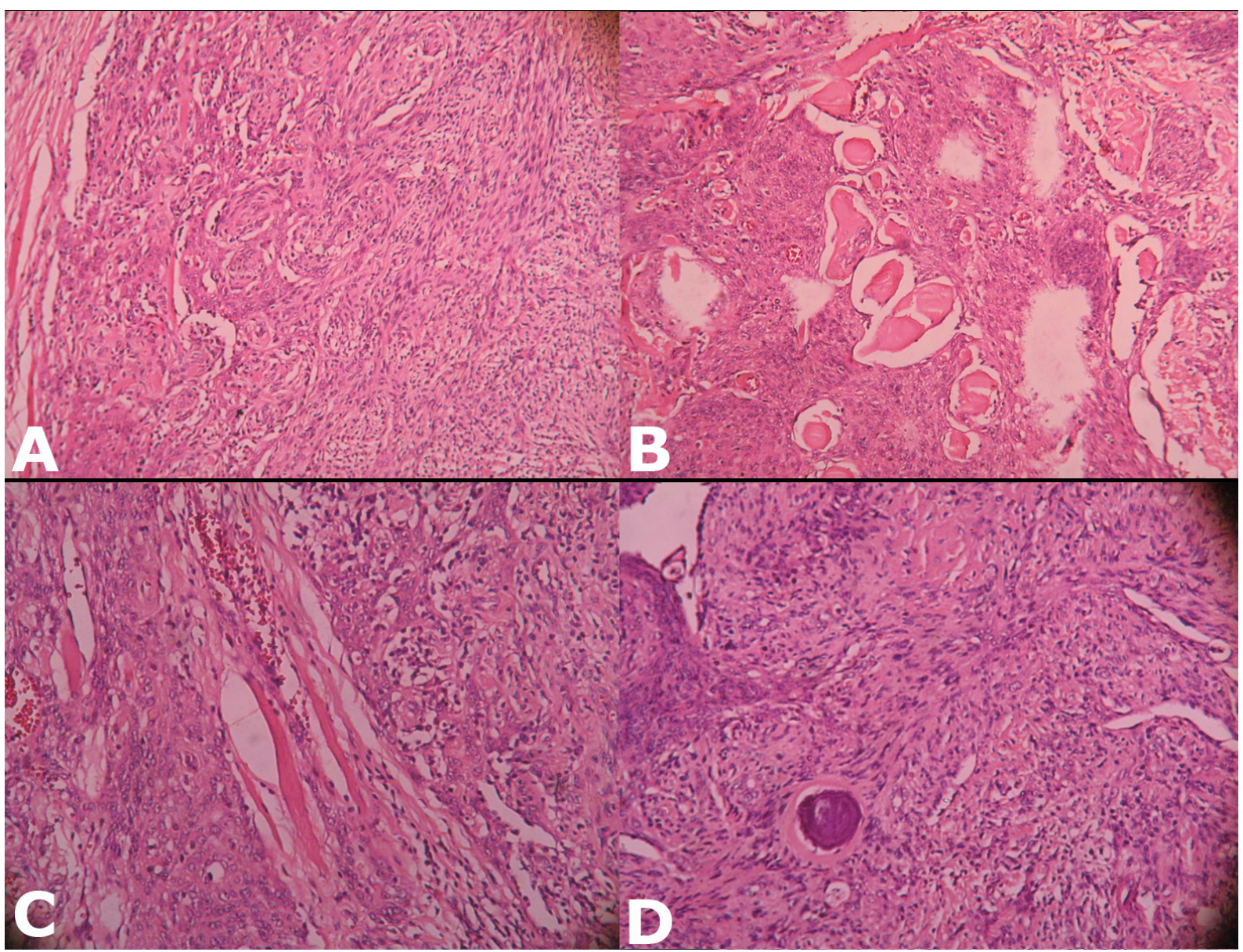

Figure 2

(A) Spindle shaped tumor cells forming whorling pattern (H\&E,X100)., (B) spindle shaped tumor cells with areas of hyalinization (H\&E,X100), (C) tumor cells infiltrating the skeletal muscle bundles and congested blood vessels (H\&E,X100) and (D) spindle shaped tumor cells with psammoma body (H\&E,X100)

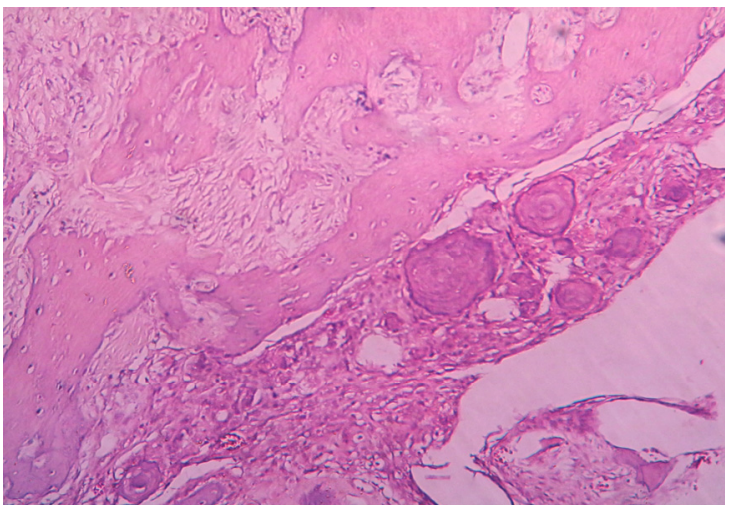

Figure 3

Showing the bony trabeculae with interstitial tissue showing infiltrating tumor cells and psammoma bodies (H\&E,X100)
In our case the tumor was in close proximity to right fronto-parietal suture and there was also a possibility that suture line could have paved the way for its extracranial spread and also there was evidence of transdiploic extension on histopatholgical examination. Clinical symptoms are usually non-specific and can be according to the site of involvement (20). If the extracranial component is large enough and there is extensive hyperostosis the lesion can be palpable through the scalp (18). Both MRI and CT will help to suggest the extent of the lesion and this can be 
confirmed by FNAC prior to surgical intervention $(4,7,24)$. Whenever possible the complete excision of the tumor is the treatment of choice as this has been shown to be associated with best long-term outcome compared with subtotal excision (19, 23, 25, 2627 28, 29). The recurrence rate ranges from $7 \%$ to $84 \%(30,31)$ and the recurrences usually develop at the primary site of lesion and probably represent the residual disease rather than true recurrence $(27,30,31)$.

\author{
Address for correspondence: \\ Dr. Amit Agrawal \\ Professor of Neurosurgery, Department of \\ Neurosurgery, Narayana Medical College \\ Hospital, Chinthareddypalem \\ Nellore-524003 \\ Andhra Pradesh (India) \\ Email:dramitagrawal@gmail.com \\ dramitin@yahoo.com \\ Mobile: +91-8096410032
}

\section{References}

1.Longstreth WT, Dennis LK, McGuire VM, Drangsholt MT, Koepsell TD. Epidemiology of intracranial meningioma. Cancer 1993;72:639-648.

2.Louis D, Ohgaki H, Wiestler O, Cavenee W, Fuller C. World Health Organization classification of tumours of the central nervous system. JOURNAL OF NEUROPATHOLOGY AND EXPERIMENTAL NEUROLOGY 2008;67:260.

3.Russell D, Rubinstein L. Pathology of tumors of the central nervous system. London: Butleeer \& Tanner 1989:421-428

4.Neeff M, Baysal E, Homer J, Gillespie J, Ramsden R. Intracranial/Extracranial meningioma arising in the hypoglossal canal: case report. Skull base : official journal of North American Skull Base Society [et al] 2007;17:325-330.

5.Cech DA, Leavens ME, Larson DL. Giant intracranial and extracranial meningioma: case report and review of the literature. Neurosurgery 1982;11:694-697.

6.Djindjian M, Raulo Y. [Giant intra-extracranial meningioma of the calvaria]. Neuro-Chirurgie 1984;30:341-345.

7.Nakagawa H, Lusins JO. Biplane computed tomography of intracranial meningiomas with extracranial extension. Journal of computer assisted tomography 1980;4:478-483.

8.Akif M. Intra-Extracranial Meningioma. Turkish Neurosurgery 1993;4:170-172.

9.Farr HW, Gray GF, Vrana M, Panio M. Extracranial meningioma. Journal of surgical oncology 1973;5:411420

10.Friedman CD, Costantino PD, Teitelbaum B, Berktold RE, Sisson GA. Primary extracranial meningiomas of the head and neck. The Laryngoscope 1990;100:41-48.

11.Preston-Martin S, Pogoda JM, Schlehofer B, et al. An international case-control study of adult glioma and meningioma: the role of head trauma. International journal of epidemiology 1998;27:579-586.

12.Barnett GH, Chou SM, Bay JW. Posttraumatic intracranial meningioma: a case report and review of the literature. Neurosurgery 1986;18:75-78.

13. Carpenter AV, Flanders WD, Frome EL, Cole P, Fry SA. Brain cancer and nonoccupational risk factors: a case-control study among workers at two nuclear facilities. American journal of public health 1987;77:1180-1182.

14.Inskip PD, Mellemkjaer L, Gridley G, Olsen JH. Incidence of intracranial tumors following hospitalization for head injuries (Denmark). Cancer causes \& control : CCC 1998;9:109-116.

15.Claus EB, Bondy ML, Schildkraut JM, Wiemels JL, Wrensch M, Black PM. Epidemiology of intracranial meningioma. Neurosurgery 2005;57:1088-1095; discussion 1088 .

16.Wiemels J, Wrensch M, Claus EB. Epidemiology and etiology of meningioma. Journal of neuro-oncology 2010;99:307-314.

17.Teague SD, Conces DJ. Metastatic meningioma to the lungs. Journal of thoracic imaging 2005;20:58-60.

18.Younis G, Sawaya R. Intracranial osteolytic malignant meningiomas appearing as extracranial softtissue masses. Neurosurgery 1992;30:932-935.

19.Thompson LD, Gyure KA. Extracranial sinonasal tract meningiomas: a clinicopathologic study of 30 cases with a review of the literature. The American journal of surgical pathology 2000;24:640-650.

20.Thompson LDR, Bouffard J-P, Sandberg GD, Mena H. Primary ear and temporal bone meningiomas: a clinicopathologic study of 36 cases with a review of the literature. Modern pathology : an official journal of the United States and Canadian Academy of Pathology, Inc 2003;16:236-245.

21.Chang CY, Cheung SW, Jackler RK. Meningiomas presenting in the temporal bone: the pathways of spread from an intracranial site of origin. Otolaryngology-head and neck surgery : official journal of American Academy of Otolaryngology-Head and Neck Surgery 
DOI: 10.2478/romneu-2013-0022

1998;119:658-664.

22.Batsakis JG. Invasion of the microcirculation in head and neck cancer. The Annals of otology, rhinology, and laryngology 1984;93:646-647.

23.Panjvani SI, Gandhi MB, Sarvaiya AN, Chaudhari BR, Gupta GS. An Extracranial Invasive Meningioma Mimicking Malignant Bone Tumor-“Carpet Meningioma". 2013.

24.Saloner D, Uzelac A, Hetts S, Martin A, Dillon W. Modern meningioma imaging techniques. Journal of neuro-oncology 2010;99:333-340.

25.Naguib SM, Shalaby AMR. Differentiation of meningiomas from histologic mimics via the use of claudin-1. Pan Arab Journal of Neurosurgery:10.

26.Condra KS, Buatti JM, Mendenhall WM, Friedman WA, Marcus Jr RB, Rhoton AL. Benign meningiomas: primary treatment selection affects survival. International Journal of Radiation Oncology ${ }^{\star}$ Biology Physics 1997;39:427-436.

27.Possanzini P, Pipolo C, Romagnoli S, et al. Primary extra-cranial meningioma of head and neck: clinical, histopathological and immunohistochemical study of three cases. Acta otorhinolaryngologica Italica : organo ufficiale della Societa italiana di otorinolaringologia e chirurgia cervico-facciale 2012;32:336-338.

28.Crawford TS, Kleinschmidt-DeMasters BK, Lillehei KO. Primary intraosseous meningioma. Case report. Journal of neurosurgery 1995;83:912-915.

29.Inagaki K, Otsuka F, Matsui T, Ogura T, Makino H. Effect of etidronate on intraosseous meningioma. Endocrine journal 2004;51:389-390.

30.Mirimanoff RO, Dosoretz DE, Linggood RM, Ojemann RG, Martuza RL. Meningioma: analysis of recurrence and progression following neurosurgical resection. Journal of neurosurgery 1985;62:18-24.

31.Stafford SL, Perry A, Suman VJ, et al. Primarily resected meningiomas: outcome and prognostic factors in 581 Mayo Clinic patients, 1978 through 1988. Mayo Clinic proceedings Mayo Clinic 1998;73:936-942. 